Известия высших учебных заведений. Прикладная нелинейная динамика. 2022. Т. 30, № 1 Izvestiya Vysshikh Uchebnykh Zavedeniy. Applied Nonlinear Dynamics. 2022;30(1)

Article

DOI: $10.18500 / 0869-6632-2022-30-1-76-95$

\title{
Revealing the neural network underlying covert picture-naming paradigm using magnetoencephalography
}

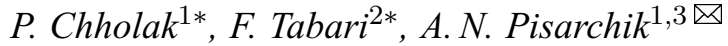 \\ ${ }^{1}$ Universidad Politécnica de Madrid, Spain \\ ${ }^{2}$ Universidad Autónoma de Madrid, Spain \\ ${ }^{3}$ Innopolis University, Russia \\ E-mail: parth.chholak@ctb.upm.es, fatemeh.tabari@estudiante.uam.es, \\ 凶alexander.pisarchik@ctb.upm.es \\ Received 10.07.2021, accepted 01.08.2021, published 31.01.2022
}

\begin{abstract}
The ability to name trivial everyday objects is a key cognitive function that is tested after head injuries or brain surgeries. Although quite a lot of long-standing knowledge on this topic has accumulated over the past few decades and many theoretical models have been created, the underlying neural substrate and brain functioning are still not fully aligned. As far as we know, there have been no studies on this topic using magnetoencephalography (MEG), which allows recording electrophysiological activity with a high temporal resolution. Therefore, to study the underlying spatio-temporal brain activations during the sensory and semantic processing of object naming, we conducted MEG experiments with 15 subjects grouped into three equal-sized groups with different types of language training and skills. Using boundary element methods for modelling cortical surfaces and dynamic statistical parametric mapping to solve the inverse problem, we reconstructed the cortical source activity from the recorded MEG data. The reconstructed cortical maps showed a homogeneous brain response in all three groups at the sensory processing stage, while the responses between the three groups at the semantic processing stage were different. In addition, average time courses were constructed for key brain regions such as the lateral occipital cortex (LO), fusiform gyrus (FG), Broca's area (BA), and Wernicke's area (WA). The obtained results assume unimodal forms for LO and WA time series, and bimodal forms for FG and BA. The only LO curve peak and the first FG peak resided in the time interval for the sensory processing stage, whereas, the only WA peak, the second FG peak and the second BA peak resided in the semantic processing stage. The first BA peak was located at the boundary separating the two stages. In addition to segregating regions involved in sensory and semantic processing, this study confirmed the involvement of FG in object naming (for the first time using MEG) that is at risk of resection during mesial temporal lobe epilepsy interventions. However, the results from this work are preliminary due to the limited sample size, and future research with a larger cohort of subjects are needed to verify/strengthen the findings of this study.
\end{abstract}

Keywords: magnetoencephalography, picture naming, object recognition, cognitive neuroscience, visual perception.

Acknowledgements. This study was supported by the Portuguese Foundation for Science and Technology and the Portuguese Ministry of Science, Technology and Higher Education (UID/PSI/01662/2019), through the national funds (PIDDAC). The data analysis was supported by the Russian Science Foundation, grant No. 19-12-00050. The authors acknowledge Dr. Adriana Sampaio and Elena Garayzábal Heinze for their role in administering the experiments, fruitful suggestions, and financial support. We would also like to thank Eduardo López-Caneda and Alberto J. González-Villar for their help and support in data collection. Lastly, we thank the participating children and their parents along with the King's College La Moraleja, Hastings School Madrid and C.E.I.P. Principe de Asturias who helped with the data collection and their invaluable input and support.

${ }^{*}$ These authors contributed equally to this work. 
For citation: Chholak P, Tabari F, Pisarchik AN. Revealing the neural network underlying covert picture-naming paradigm using magnetoencephalography. Izvestiya VUZ. Applied Nonlinear Dynamics. 2022;30(1):76-95. DOI: 10.18500/0869-66322022-30-1-76-95

This is an open access article distributed under the terms of Creative Commons Attribution License (CC-BY 4.0).

Научная статья

УДК 530.182, 612.821.1

DOI: $10.18500 / 0869-6632-2022-30-1-76-95$

\title{
Выявление нейронной сети, лежащей в основе парадигмы скрытого наименования изображений, с помощью магнитоэнцефалографии
}

\author{
П. Чхолак ${ }^{1 *}$, Ф. Табари ${ }^{2 *}$, А.Н. Писарчик ${ }^{1,3 凶}$ \\ ${ }^{1}$ Мадридский технический университет, Испания \\ ${ }^{2}$ Мадридский автономный университет, Испания \\ ${ }^{3}$ Университет Иннополис, Россия \\ E-mail: parth.chholak@ctb.upm.es, fatemeh.tabari@estudiante.uam.es, \\ \alexander.pisarchik@ctb.upm.es \\ Поступила в редакиию 10.07.2021, принята к публикачии 01.08.2021, \\ опубликована 31.01.2022
}

\begin{abstract}
Аннотация. Цель работы - исследовать пространственно-временную активность мозга, вызываемую сенсорными и семантическими процессами во время именования объектов. Для этого были проведены эксперименты по магнитоэнцефалографии (МЭГ) с пятнадцатью субъектами, которые были поделены на три равные по размеру группы с разными типами языковой подготовки и навыков. Методы и результаты. Анализ записанных МЭГ-данных с применением метода граничных элементов для моделирования корковых поверхностей, а также использование динамического статистического параметрического отображения для решения обратной задачи, позволили реконструировать активность кортикального источника. Восстановленные корковые карты показали однородный ответ мозга во всех трех группах на стадии сенсорной обработки, в то время как ответы между тремя группами на стадии семантической обработки были разными. Кроме того, были построены средние временные курсы для ключевых областей мозга, таких как латеральная затылочная кора (LO), веретенообразная извилина (FG), область Брока (BA) и область Вернике (WA). Полученные результаты принимают унимодальные формы для временных рядов LO и WA и бимодальные формы для FG и BA. Единственный пик кривой LO и первый пик FG находятся во временном интервале стадии сенсорной обработки, тогда как единственный пик WA, второй пик FG и второй пик BA - на стадии семантической обработки. Первый пик ВА расположен на границе, разделяющей две стадии. В дополнение к разделению областей, участвующих в сенсорной и семантической обработке, наше исследование подтвердило участие FG в именовании объектов (впервые с использованием МЭГ), которые подвержены риску резекции во время вмешательств при мезиальной височной эпилепсии. Заключение. Способность называть тривиальные повседневные предметы является ключевой когнитивной функцией, которая тестируется после травм головы или операций на головном мозге. Получено новое понимание механизмов скрытого наименования картинок и их нейронального субстрата. Результаты работы подчеркивают важность веретенообразной извилины, которая подвержена риску резекции при мезиальной височной эпилепсии. Однако полный механизм этапа семантической обработки является более сложным и требует доработки. По-видимому, существуют двунаправленные связи между трехфокальной сетью, образованной веретенообразной извилиной, областью Брока и областью Вернике, и их причинно-следственные связи необходимо исследовать в будущем, как и связи этой сети с внутрипариетальной бороздой. Следует также разработать надежный метод определения пиков вызванных откликов.
\end{abstract}

Ключевые слова: магнитоэнцефалография (МЭГ), наименование изображений, распознавание объектов, когнитивная нейробиология, визуальное восприятие.

Благодарности. Это исследование было поддержано Португальским фондом науки и техники и Португальским Министерство науки, технологий и высшего образования (UID/PSI/01662/2019), через национальные фонды (PIDDAC). Анализ данных был проведен при поддержке Российского научного фонда, грант № 19-12-00050. Авторы выражают признательность доктору Адриане Сампайо и Елене Гарайзабал Хайнце за их роль в проведении экспериментов, плодотворные предложения и финансовую поддержку. Мы также хотели бы поблагодарить Эдуардо Лопеса-Канеду и Альберто Дж. Гонсалеса-Вильяра за их помощь и поддержку в сборе данных. Наконец, мы благодарим участвующих детей и их родителей, а также Королевский колледж Ла Моралеха, Гастингс Школа Мадрида и С.Е.І.Р. Принсипи де Астурия, которые помогли со сбором данных и оказали неоценимую помощь и поддержку.

*Эти авторы внесли равный вклад в эту работу. 
Для цитирования: Чхолак П., Табари Ф., Писарчик А. Н. Выявление нейронной сети, лежащей в основе парадигмы скрытого наименования изображений, с помощью магнитоэнцефалографии // Известия вузов. ПНД. 2022. Т. 30 , № 1. C. 76-95. DOI: 10.18500/0869-6632-2022-30-1-76-95

Статья опубликована на условиях Creative Commons Attribution License (CC-BY 4.0).

\section{Introduction}

Accessing semantic memory can be defined as recollecting the meaning of a noun, generalisable to any context $[1,2]$. Numerous neuropsychological studies support the role of ventral temporal cortex in semantic memory [3,4], including ones based on electrical cortical stimulation [5,6], positron emission tomography (PET) [7-11], magnetoencephalography (MEG) [12] and intracranial event-related potential (ERP) $[13,14]$. These studies span the entire ventral temporal cortex, from the temporal pole and through the fusiform gyrus (FG). It is noteworthy that in a number of reviews, these brain areas are completely ignored, and the semantic function is assigned exclusively to the lateral temporal regions [15-18]. However, a recent study by Forseth et al. [19] convincingly argues that semantic memory is located in the FG, which previously has also been referred to as the basal temporal language area $[5,6]$.

A popular paradigm for studying semantic memory is picture-naming, which includes an auditory or visual description of an object, followed by the naming of that object by the participant $[19,20]$. The naming can either be overt when the subject speaks the name out loud, or it can be covert, which means that the subject mentally rehearses saying the name but does not actually say it.

Cognition in the picture-naming task can be divided into three stages, gradually progressing with a clear functional specialization [21]: (1) sensory processing, (2) semantic processing, and (3) articulation. These stages were distinguished in a recent electrocorticography (ECoG) study using spatiotemporal broadband gamma activity (BGA) patterns [19]. The researchers found that the place and timing of sensory processing depends on the sensory modality used to describe the object to be named. In the case of visual picture-naming, it was localized in the lateral occipital (LO) cortex. Activation spreads forward along two hierarchical visual processing streams from the early visual cortex [22,23]: (I) Ventral stream - caudal to rostral FG and (II) Dorsal stream - occipital pole to the intraparietal sulcus (IPS).

After the sensory processing stage, both auditory and visual naming experiments demonstrate concurrent activity in FG, IPS, inferior frontal gyrus (IFG), and supplementary motor area (SMA) in contrast to the presentation of nonsensical stimuli [19]. The activity in the SMA is accompanied by sensorimotor activations corresponding to the articulation unlike other three regions that precede any such sensorimotor activity. Therefore, the neural substrate of semantic processing can be reduced to a three-locus brain network comprising of FG, IPS and IFG.

It is generally accepted that IFG is involved in semantic selection and phonological processing [24-26] segregated along an anterior-posterior axis [27,28]. The anterior pars triangularis (Brodmann region 45) performs top-down control of the semantic network, possibly with feed-forward and feedback information encoded in distinct frequency bands [29,30]. At the same time, the posterior pars opercularis (Brodmann area 44) controls the language production aspects. These two areas together form the Broca's area (BA), widely recognised as a critical component for speech production [31,32]. Although the exact nature of speech production is not yet known, there is some evidence that BA coordinates the activity of the cerebral cortex to convert information into motor codes of the cortex to produce words [33]. In fact, BA acts as an interface between the lexical-semantic and articulatory networks. Direct cortical stimulation of this area results in a modality-independent naming deficit, i.e. inability to the name the object described either visually or auditorily [19].

It should be noted that FG and IPS are critical for semantic encoding. The study by Forseth et al. [19] showed lesser overlap of the heteromodal semantic network in IPS than in FG, probably 
because the task was focused on common object-naming rather than action-naming, which can involve more parietal regions [34-36]. Whereas, direct cortical stimulation of the FG leads to speech arrest [6]. Atrophy and hypometabolism in the anterior FG has also been documented in patients with semantic dementia [37,38].

Another brain region relevant here is the Wernicke's area that has been designated diverse roles in different language studies. In particular, it has been considered a secondary region engaged with IFG in semantic control [28,39], a central site for semantic representation [18], or a lexical interface [26]. In the recent review of the area by Binder [40], he discussed the variability in its localisation across subjects and studies, and generalised its location to Brodmann areas 22 (posterior superior temporal gyrus or pSTG) and 40 (supramarginal gyrus) that surround the left posterior sylvian fissure. However, the functional definition of the area can lead to its localisation virtually anywhere in the temporal cortex. For instance, it was localised to the posterior middle temporal gyrus (pMTG) in the work of Forseth et al. [19]. Therefore, for the purposes of our research that closely matches the study of Forseth et al. [19], we will use Brodmann area 22 which is adjacent to the pMTG as the Wernicke's area.

As mentioned above, the involvement of the ventral temporal lobe is disputed, and further investigation is needed to confirm and characterize its role. This region is especially at risk during surgical resections for mesial temporal lobe epilepsy [19]. Curiously, minimally invasive approaches such as laser interstitial thermal ablation, which generally spare the FG, show a reduction in post-operational deficits such as object naming, further highlighting the role of FG in semantic processing [41,42]. Further, the individual roles of each of the studied areas and their coordinated activity are not completely understood and require further investigation. Therefore, the goal of this study is to reveal the spatiotemporal activation patterns from the lenses of MEG in performing the covert picture-naming of common objects and thus, to understand the likely roles of the involved language processing areas such as IFG (Broca's area), FG, pSTG (Wernicke's area), and LO. In the process, we also validate the involvement of ventral temporal regions such as FG.

In order to segregate the stages of sensory processing and semantic processing, we designed the experiment in a foreign language with subjects divided in different groups of equal sizes based on their language proficiencies and mode of language schooling. We expected sensory processing stage to be homogeneous among the three groups and the semantic processing stage to be heterogeneous.

\section{Materials and methods}

Our study involved fifteen children who speak English as a second language. All participants were right-handed with no history of neurological or cognitive impairment. Right-handedness or lefthemispheric language dominance was validated using Edinburgh Handedness Inventory [43]. Their English proficiency scores were tested using the Oxford Quick Placement Test which can have a maximum score of 60 .

The participants were divided into three group ( $N=5$ subjects in each group) based on their mode of language schooling. Group-1 is formed by children who were taught English as a Foreign Language (EFL) for at least 5 hours/week. These students have the lowest proficiencies, but not so low as to lose comparability (score $41.00 \pm 2.07$ ). Group-2 includes children belonging to Content and Language Integrated Learning (CLIL) system with intermediate levels of English proficiency (score $46.40 \pm 2.59$ ). Essentially, CLIL involves teaching certain subjects such as natural sciences, social sciences, and arts and crafts in a foreign language such as English. These students receive a weekly English training of at least 11 hours/week including EFL and the other aforementioned subjects. Finally, Group-3 is formed by highly-proficient children (score $55.00 \pm 1.46$ ) that belong to the immersion 
teaching program [44] taught in two British schools of Madrid, Spain. Herein, all courses are taught in English, except social studies and Spanish language, for at least 25 hours/week. No significant differences in non-verbal intelligence were found between the groups as per the Raven's SPM 60-item test. One of the subjects from Group-3 (Subject-7) was later excluded from analysis due to highly noisy data.

All participants resided in Madrid, Spain. The mean ages of children in Groups- 1 and 2 were 11.4 years and was 12.0 years in Group-3. The age difference is due to the heterogeneous classification of grades in different schools, i.e., the 5th grade of one school is equivalent to the 6th grade of another school. The gender distribution in each group was roughly balanced $(3,2$, and 3 females out of 5 subjects in Groups-1, 2, and 3, respectively).

The experiments were carried out between 2015 and 2018, and approved by the local Ethics Committee. Written informed consents were obtained from the parents of all children who voluntarily participated in this study. All analyses were carried out using MNE-Python 0.22.0 [45], except for the statistical analysis which was carried out in MATLAB R2019a.

1.1. Stimuli and task. During the data acquisition, the participants completed a covert visual picture-naming task to avoid muscle contamination artifacts. The task consisted of 120 trials divided into two blocks of 60 images each, presented in a pseudo-random order in which the participants were asked to mentally rehearse naming the object shown in a picture, e.g., "bat" or "tree". The stimulus images were presented for $3000 \mathrm{~ms}$, followed by a blank screen for a variable duration of 1700-2300 ms. Therefore, each trial lasted for approximately 5 seconds and the total experiment duration was close to 12 minutes. The stimuli were selected from a set of pre-normalised description naming cues, MultiPic databank (https://www.bcbl.eu/databases/multipic), and presented using Psychopy software [46].

1.2. MEG recording and preprocessing. Brain activity was recorded with the Elekta Neuromag® (Elekta AB, Stockholm, Sweden) magnetoencaphalography (MEG) whole-head scanner (102 magnetometers and 204 planar gradiometers) inside a magnetically shielded room (VacuumSchmelze GmbH, Hanau, Germany) at the Center for Biomedical Technology, Universidad Politécnica de Madrid, Spain. The participants sat comfortably $135 \mathrm{~cm}$ from a translucent screen onto which the stimuli were projected. Their legs were extended, and their hands were either on their knees or on an armrest in front of them. Digital models of the head shape of each subject were determined prior to the MEG recording using a digitizer (3D Space Fast-Track, Polhemus, Colchester, VT, USA) that were co-registered with three anatomical reference points (nasion, left and right preauricular). Channels with poor signal quality were manually removed from consideration after visual inspection for artifacts, and a temporal Signal-Space Separation (tSSS) filter was applied for artifact removal using MaxFilter software (v2.2). The length of raw data buffer was changed from the default value of 4 to 10 seconds for more efficient suppression of internal interference, while the subspace correlation limit was set as 0.98 . The signals from the removed noisy channels were replaced with the weighted average signals of the neighbouring channels depending on their respective distances. The head position relative to the MEG scanner was continuously monitored using four head position indicator (HPI) coils placed around the head.

Vertical electrooculogram and electrocardiogram activity were also recorded using dedicated channels for subsequent correction of artifacts from eye blinking and cardiac activity. The sampling rate was $1000 \mathrm{~Hz}$, and an online anti-aliasing bandpass filter was implemented in the range 0.1-330 Hz. The recorded data were converted and stored in the Brain Imaging Data Structure (BIDS) format [47].

While analysing the raw data, we identified the time instants of stimulus presentation from the events $\log$ generated using a parallel port channel connecting the stimulus presenting computer to the MEG recording computer. Due to an inherent 56-ms average delay of the graphic card, the actual 
stimulus appeared on the screen after this specified delay for logged events. Therefore, we adjusted this delay in all subsequent analysis.

Due to technical errors, it was impossible to record electrocardiographic (ECG) activity of Subjects 7-15. In addition, both ECG and electrooculography (EOG) were not recorded for Subject 5. As a result, we applied subspace-projection (SSP) correction only for eye blinks in all subjects except Subject 5 for whom no artefact removal was performed. After artifact removal, the raw data were processed using a 1-20 Hz bandpass filter with zero-lag finite impulse response (FIR) and Hamming windowing.

$N=120$ trials ( -500 to $1000 \mathrm{~ms}$ ) corresponding to the total number of presented images were generated for each subject. Then, the baseline was adjusted using data from $-500 \mathrm{~ms}$ to $0 \mathrm{~ms}$ in each trial. Due to technical problems, the total number of trials were less than 120 for some subjects. The number of images shown to each subject are presented in Table 1.

Table 1. Total number of pictures shown

\begin{tabular}{|c|c|c|c|c|c|c|c|c|c|c|c|c|c|c|c|}
\hline Subject & 1 & 2 & 3 & 4 & 5 & 6 & 7 & 8 & 9 & 10 & 11 & 12 & 13 & 14 & 15 \\
\hline Group & 2 & 3 & 1 & 1 & 1 & 2 & 3 & 3 & 3 & 2 & 2 & 3 & 1 & 1 & 2 \\
\hline Pictures & 120 & 120 & 120 & 120 & 120 & 120 & 111 & 98 & 82 & 89 & 85 & 87 & 87 & 89 & 83 \\
\hline
\end{tabular}

The time series of $N$ trials were time locked to the image presentation moment and they were averaged for each subject to produce event-related fields (ERF).

1.3. Source reconstruction. The standard default anatomy from FreeSurfer [48] was warped to match the digitized head points recorded with the Polhemus Fastrak device. The surface-based source space was tuned using recursively subdivided octahedron spacing, and then a geometric brain model was created using the boundary element method (BEM). The surface was downsampled to 5120 points, and a single layer model with a conductivity of $0.33 \mathrm{~S} / \mathrm{m}$ was used. Finally, the BEM solution was created using a linear collocation approach. Using the BEM model and source space, a direct solution was generated, which was essentially a transformation of the source space activity to the recorded channel space activity based on the head geometry and conductivity, also known as forward model. The source orientations were based on the brain surface. Additionally, the elements of the forward model matrix were scaled using predetermined factors to account for the differences in magnetometer and gradiometer recordings of the same cortical activity.

To compute the inverse solution, we needed, in addition to the forward model, a noise covariance matrix, which was obtained by calculating the sample coherence from the baseline period of each epoch, i.e., from -500 to 0 ms. Thus, noise covariance matrix was calculated from individual epochs without averaging. The inverse operator was then assembled with a strong emphasis on radial activity. The source variances of tangential dipole components were weighted by a factor of 0.2 to ensure the indicated emphasis to radial activity. Additionally, since deeper brain sources have significantly less influence on recorded data than cortical activity that is closer to the surface, the forward model was normalised using exponential depth-weighting with an exponent of 0.8 .

The inverse problem is an ill-posed problem in that it has infinite solutions as the degrees of freedom (number of modelled brain sources) far exceed the number of constraints (number of channels). Thus, the excessive degrees of freedom are handled using regularisers based on some assumed priors regarding the solution. Three widely popular approaches to solve the inverse problem respectively aim for solutions with minimum norm, minimum variance, or fitting a small number of equivalent current dipoles in the brain. Here, we used the dynamic statistical parametric mapping (dSPM) technique [49] which is a minimum variance method with the regularisation parameter set to the default value of 
$(1 / 3)^{2}=0.111$. At each source location, the source activity was estimated as the vector norm of all tangential and radial source activities.

Thus, we obtained an inverse solution showing the estimated average brain source activity underlying the recorded MEG data upon stimuli presentation. The activity of cerebral cortex could then be observed in an interactive figure, showing different images at different times.

1.4. Evoked responses in regions of interest. From the ERFs in the channel space, we estimated the evoked response in the source space using the inverse operator and smoothened the time courses using the Savitzky-Golay filter with 251-ms window size and polynomial order 3 as in the work done by Forseth et al. [19].

To find a representative time course of the brain sources located in regions such as LO, FG, BA and WA, we used the first right singular vectors after applying singular value decomposition to all the time courses in the regions of interest. These signals were then scaled to match the average per-vertex power in the corresponding region of interest. First, the dominant source orientations in each region were determined, and then a sign flip was applied to all sources, the directions of whom were opposite to the dominant one.

In addition, we averaged the ERF for subjects belonging to the three groups, and a global average ERF for all subjects was also calculated. A weighted average was used considering the total number of trials for each subject according to Table 1 in order to account for the inter-subject variability in total number of trials. We used Desikan-Killany atlas to mark the LO and the FG, and Brodmann atlas to mark the BA and the WA.

1.4.1. Statistical analysis. The most prominent local peaks in the evoked responses were evaluated after setting a minimum prominence level of 5\% peak-to-peak amplitude for a peak to be identified. The average amplitudes and latencies of these peaks were then independently studied. The number of samples in each group were 5 except in Group-3 which had 4 samples after dropping Subject-7. The significance level $\alpha$ was kept to be 0.05 . The differences between the average peak amplitudes and latencies of all the groups in pairs of two were checked for statistical significance via a post-hoc power analysis. The standard deviation was estimated using the pooled standard deviation $\left(\sigma_{p}\right)$ approach over any two groups, Group- $i$ and Group- $j$, such that

$$
\sigma_{p}=\sqrt{\frac{\left(n_{i}-1\right) \sigma_{i}^{2}+\left(n_{j}-1\right) \sigma_{j}^{2}}{n_{i}+n_{j}-2}} .
$$

The sample size was kept to be 5 for comparisons between Group-1 and 2, whereas it was conservatively kept as 4 in the other two cases involving Group-3.

\section{Results}

2.1. Cortical activation maps. Cortical activation maps obtained from source localisation were time-averaged in the intervals: $0-250$ and $250-750 \mathrm{~ms}$ post-stimulus onset to capture the prominently active regions in the sensory and semantic processing stages, respectively. The respective average cortical maps for all the three groups are shown in Figs. 1, 2, and 3.

During the first $250 \mathrm{~ms}$ or the sensory processing stage, the cortical maps are similar for all three groups; visual inspection shows activations in lateral occipital cortex (LO), intraparietal sulcus (IPS), fusiform gyrus (FG), precuneus, and lingual gyrus. Over the next period from 250-750 ms or the semantic processing stage, the activation maps intensify and spread forward. All groups show activations in LO, Wernicke's area (WA), Broca's area (BA), FG, IPS, superior temporal sulcus (STS), hippocampal gyrus, and precuneus. Simple eyeballing suggests that in contrast to Group-2, BA is more strongly activated in Group-1, while in Group-3 the activity is partial. 

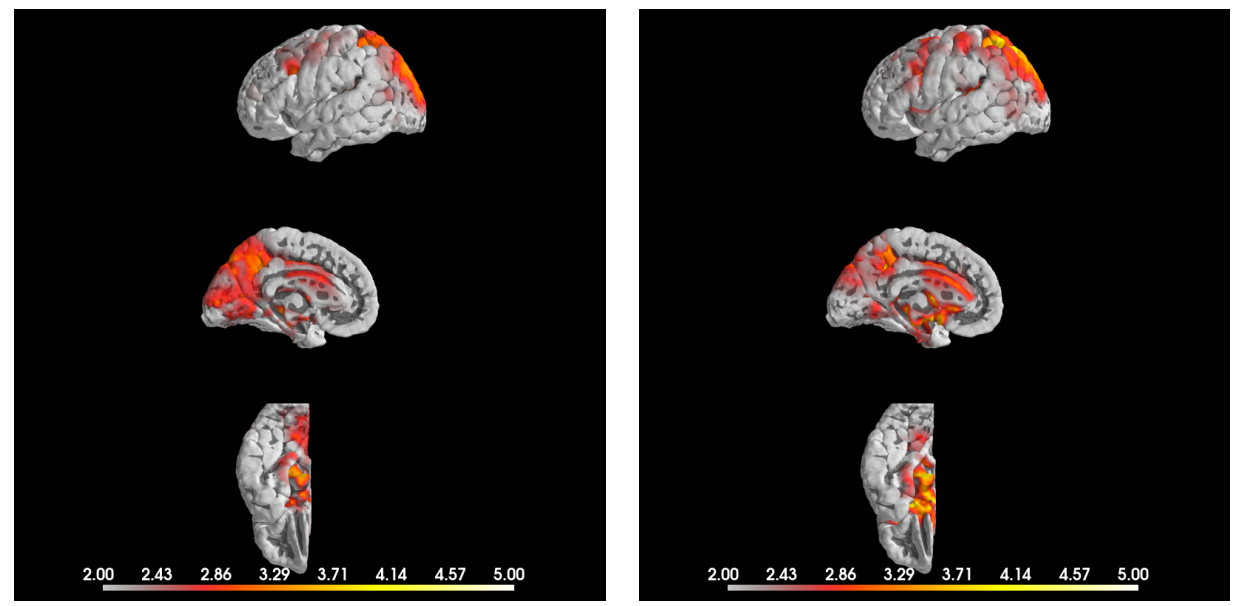

Fig. 1. dSPM cortical maps for Group-1 averaged over 0-250 ms (LEFT) and 250-750 ms (RIGHT) (color online)
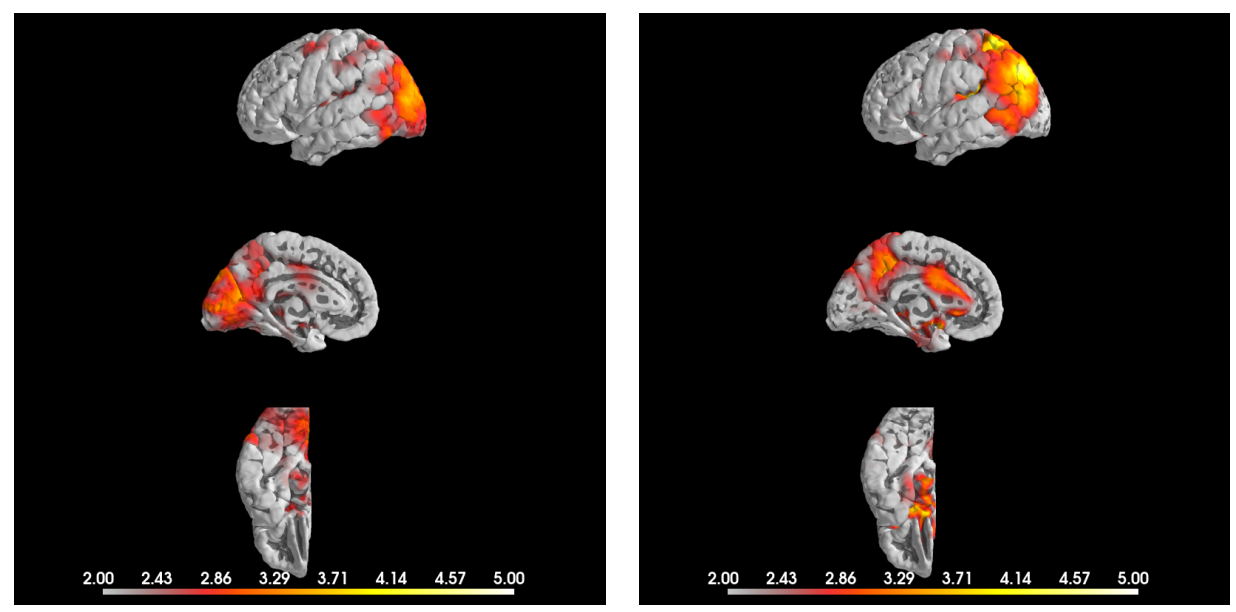

Fig. 2. dSPM cortical maps for Group-2 averaged over 0-250 ms (LEFT) and 250-750 ms (RIGHT) (color online)
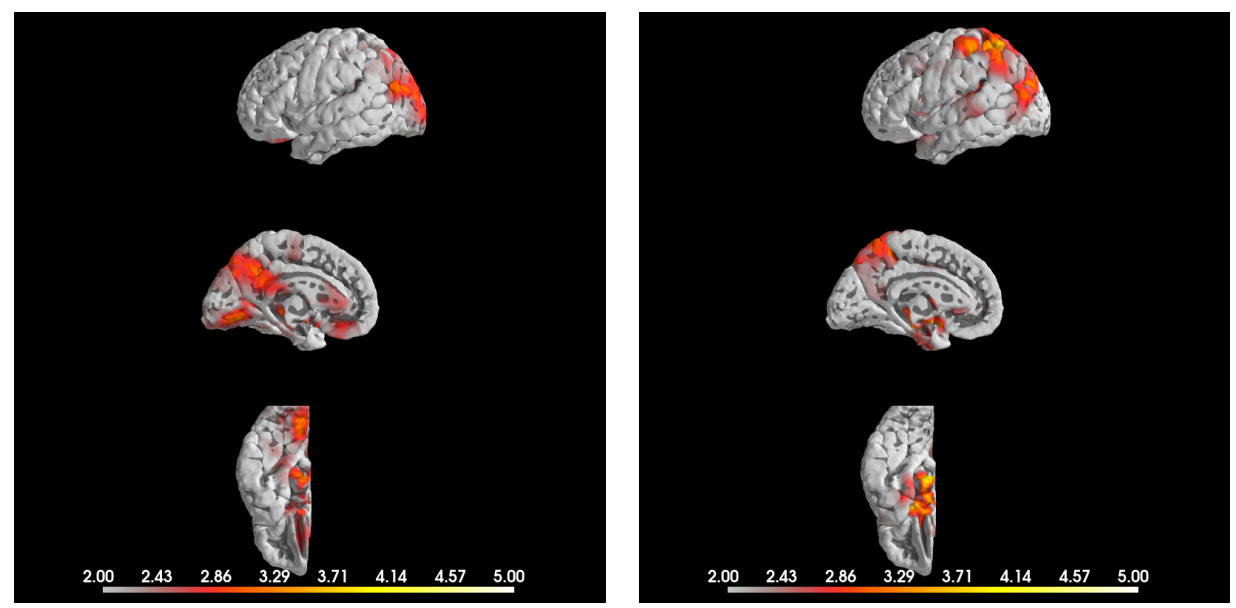

Fig. 3. dSPM cortical maps for Group-3 averaged over 0-250 ms (LEFT) and 250-750 ms (RIGHT) (color online) 

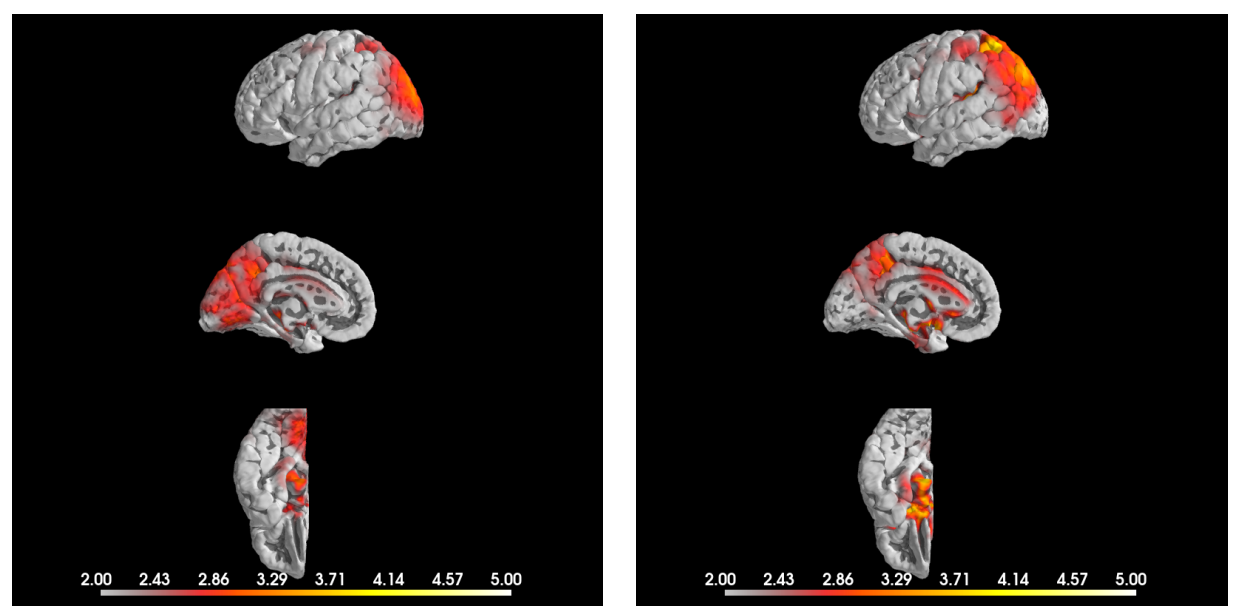

Fig. 4. dSPM cortical maps for all subjects averaged over 0-250 ms (LEFT) and 250-750 ms (RIGHT) (color online)

The cortical maps of the two stages averaged over all participants are shown in Fig. 4. An interesting observation is that activity from the early visual cortex is seen spreading forward ventrally from caudal to rostral FG, and dorsally from the occipital pole to the IPS, as was expected from the discussion in Introduction. Additionally, we also see a migration of activity from the cuneus and lingual gyrus towards the anterior cingulate and hippocampal gyrus.

2.2. Average source time-courses in regions of interest. We then estimated the intra-group average of the source time-courses corresponding to the four regions of interest. The evoked responses in LO, BA, WA, and FG for Groups 1, 2, and 3 are shown in Figs. 5, $a, b$ and $c$, respectively. The vertical
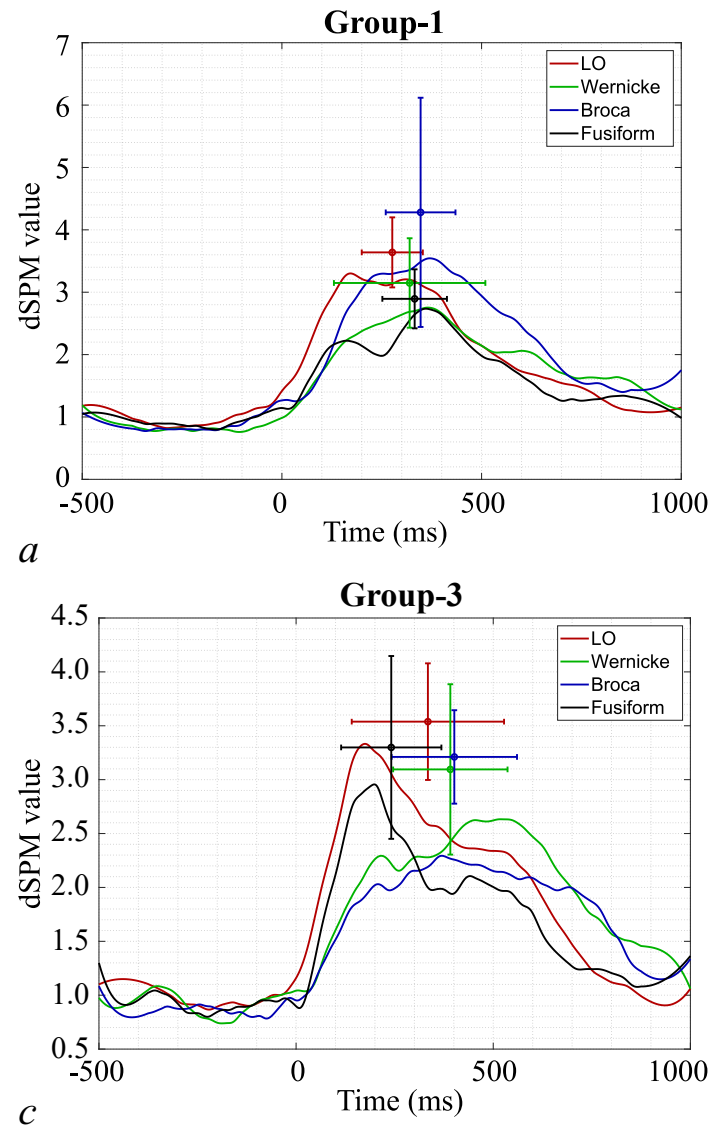

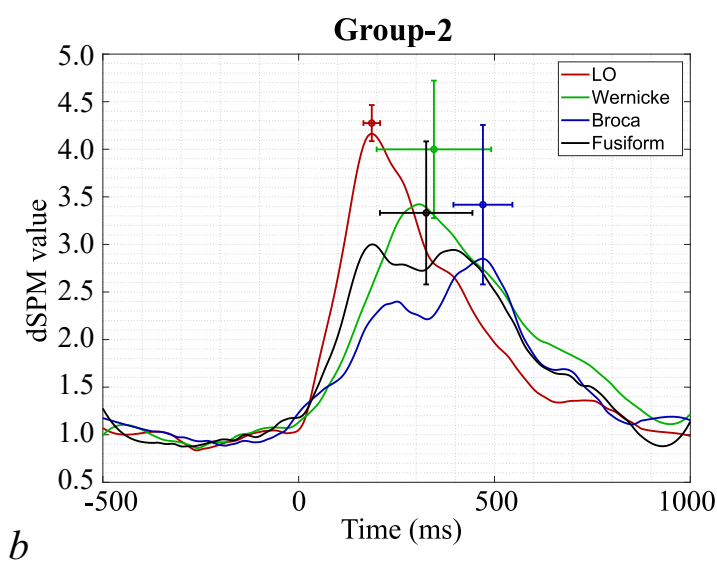

Fig. 5. Evoked response in regions of interest for (a) Group-1, (b) Group-2, and (c) Group-3. The vertical and horizontal error bars represent the standard deviations of the peak amplitudes and latencies among the considered group of subjects. The location of the error bars correspond to the mean peak amplitudes and latencies (color online) 
and horizontal error bar magnitudes are double the standard deviations of the peak amplitudes and latencies, respectively. Each error bar is located at the coordinates corresponding to the mean amplitude and latency of the most prominent peak of the evoked response curve it corresponds to.

2.2.1. Power analysis of region-wise peak latencies. A common feature for all three groups is that the LO and FG are activated first, followed by WA and BA. Particularly, the region-wise mean latencies in all three groups are as shown in Table 2. However, this promptness of LO wasn't found to be statistically significant in most subjects. As shown in Table 3, only Group-2 showed significant promptness of LO in comparison to the other 3 brain areas. Further, we note from both Fig. 5 (eyeballing) and Table 3 (power analysis) that the responses from the four regions were most distinctive in Group-2, followed by Group-3 and then by Group-1. Due to high inter-subject variability and lack of a sharp unimodal LO response in individual subjects, the prominent LO peak is not correctly identified and hence, the LO promptness is not statistically significant.

Table 2. Region-wise mean latencies (ms)

\begin{tabular}{|c|c|c|c|c|}
\hline ROI & LO & WA & BA & FG \\
\hline Group-1 & 276 & 320 & 347 & 332 \\
Group-2 & 187 & 345 & 470 & 326 \\
Group-3 & 334 & 391 & 401 & 241 \\
\hline All subjects & 261 & 348 & 405 & 305 \\
\hline
\end{tabular}

Table 3. Power analysis of region-wise mean latency differences. Percentage power denoting statistical significance of differences in mean latencies of each region

Group-1

Group-2

\begin{tabular}{|c|c|c|c|c|}
\hline$\%$ & LO & WA & BA & FG \\
\hline LO & - & 14.02 & 48.24 & 37.41 \\
WA & - & - & 9.79 & 6.92 \\
BA & - & - & - & 9.50 \\
FG & - & - & - & - \\
\hline
\end{tabular}

\begin{tabular}{|c|c|c|c|c|}
\hline$\%$ & LO & WA & BA & FG \\
\hline LO & - & $\mathbf{8 6 . 9 2}$ & $\mathbf{1 0 0 . 0 0}$ & $\mathbf{9 0 . 8 6}$ \\
WA & - & - & 63.21 & 8.62 \\
BA & - & - & - & $\mathbf{8 4 . 7 2}$ \\
FG & - & - & - & - \\
\hline
\end{tabular}

Group-3

\begin{tabular}{|c|c|c|c|c|}
\hline$\%$ & LO & WA & BA & FG \\
\hline LO & - & 13.24 & 14.83 & 22.65 \\
WA & - & - & 6.20 & 51.86 \\
BA & - & - & - & 52.61 \\
FG & - & - & - & - \\
\hline
\end{tabular}

One can see that the delay in WA and BA peaks was most pronounced, although insignificantly, in Group-2 $(P=63.21 \%)$ as opposed to the delays in Group-1 $(P=9.79 \%)$ and Group $3(P=6.20 \%)$. In both Group-1 and 2, we see that BA has a bimodal response and the second peak is consistently identified as the prominent peak, whereas WA seemingly has a unimodal response and the prominent peak is identified in the vicinity of its peak. On the other hand, the definition of the peaks is less clearer in Group-3. Although, manual inspection of Fig. 5 suggests that the WA and BA responses of Group-3 have drifted to the right in comparison to Group-2, the prominent peaks still remain in the centre. Thus, even though we observe WA and BA responses to be occurring later than the first FG peak in Group-3, the differences were not significant (WA: $P=51.86 \%$; BA: $P=52.61 \%$ ). Whereas in Group-2, significant promptness of FG was only observed versus BA $(P=84.72 \%)$. All three groups showed bimodal FG responses. It is interesting to see that the identified prominent peaks are different in the three groups. In Group-1, the second FG peak has a higher amplitude more commonly and therefore, 
the identified prominent peak is the second FG peak which belongs to the semantic processing stage. Whereas in Group-3, the amplitudes of the first peak are generally higher and therefore, the first peak is identified as the prominent peak which belongs to the sensory processing stage. Since the amplitudes of the two FG peaks are much closer in Group-2, the prominent peak is localised somewhere in the middle of the two peaks. Nonetheless, we still see significant delay between the BA response and the intermediate FG peak in Group-2 $(P=84.72 \%)$. Group-1 showed no such significant delay between the FG response, and the WA $(P=6.92 \%)$ and the BA $(P=9.50 \%)$ response as the second FG peak is supposed to concur WA and BA peaks during the semantic processing stage.

2.2.2. Power analysis of region-wise peak amplitudes. The region-wise mean amplitudes of the most prominent peaks in each group are tabulated in Table 4. Their differences too were inspected for statistical significance and the results of the corresponding power analysis are shown in Table 5 . The amplitudes were more distinguishable in Group-1 and 2 than in Group-3. The LO responses were generally the highest except in Group-1 where the BA response was insignificantly higher $(P=22.35 \%)$. In both Group-1 and 2, the FG response was the lowest and there was significant difference between the FG and the LO peaks for both (Group-1: $P=83.51 \%$; Group-2: $P=93.02 \%$ ). Taking FG as a datum in both, we notice some interesting behaviour in the two groups. In Group-1, BA response was higher than the lowest response among all regions, i.e. the FG response, although the difference in amplitudes was not significant $(P=60.31 \%)$. On the other hand, in the same group, the WA response was even closer to the FG response leading to an even more insignificant difference $(P=19.46 \%)$. Whereas in Group-2, we see such an amplified-but-insignificantly-higher response for WA $(P=51.27 \%)$ which is greater than the BA response $(P=7.49 \%)$. In fact, the BA response in Group-2 is that low so as to be significantly lower than the highest region-wise response, i.e., the LO response $(P=82.50 \%)$. This trend of downplayed BA response was also seen in Group-3, although insignificantly $(P=27.49 \%)$.

Table 4. Region-wise mean peak amplitudes (dSPM)

\begin{tabular}{|l|c|c|c|c|}
\hline \multicolumn{1}{|c|}{ ROI } & LO & WA & BA & FG \\
\hline Group-1 & 3.6386 & 3.1479 & 4.2803 & 2.8939 \\
Group-2 & 4.2751 & 3.9990 & 3.4174 & 3.3312 \\
Group-3 & 3.5382 & 3.0951 & 3.2109 & 3.2990 \\
\hline All subjects & 3.8340 & 3.4314 & 3.6868 & 3.1573 \\
\hline
\end{tabular}

Table 5. Power analysis of region-wise mean peak amplitude differences.

Percentage power denoting statistical significance of differences in mean peak amplitudes of each region

Group-1

\begin{tabular}{|c|c|c|c|c|}
\hline$\%$ & LO & WA & BA & FG \\
\hline LO & - & 40.93 & 22.35 & $\mathbf{8 3 . 5 1}$ \\
WA & - & - & 44.49 & 19.46 \\
BA & - & - & - & 60.31 \\
FG & - & - & - & - \\
\hline
\end{tabular}

\begin{tabular}{|c|c|c|c|c|}
\hline$\%$ & LO & WA & BA & FG \\
\hline LO & - & 25.23 & $\mathbf{8 2 . 5 0}$ & $\mathbf{9 3 . 0 2}$ \\
WA & - & - & 39.64 & 51.27 \\
BA & - & - & - & 7.49 \\
FG & - & - & - & - \\
\hline
\end{tabular}

Group-3

\begin{tabular}{|c|c|c|c|c|}
\hline$\%$ & LO & WA & BA & FG \\
\hline LO & - & 26.81 & 27.49 & 13.34 \\
WA & - & - & 8.78 & 10.60 \\
BA & - & - & - & 7.56 \\
FG & - & - & - & - \\
\hline
\end{tabular}


Figure 6 shows the evoked responses in the regions of interest averaged over all subjects. For LO and WA, there are single distinguishable peaks. Whereas for BA and FG, there are two peaks. Even though the prominent LO peak is placed slightly to the right of the peak in the LO curve, the latency analysis showed that the LO response was earlier than the second peak of the BA response $(P=99.69 \%)$. Whereas, the difference between the latencies of the LO peak and the WA peak was high but not significant $(P=73.86 \%)$. The prominent FG peak was localised in the middle of the two FG peaks was not significantly far in time from either the LO peak $(P=40.66 \%)$ or the WA peak

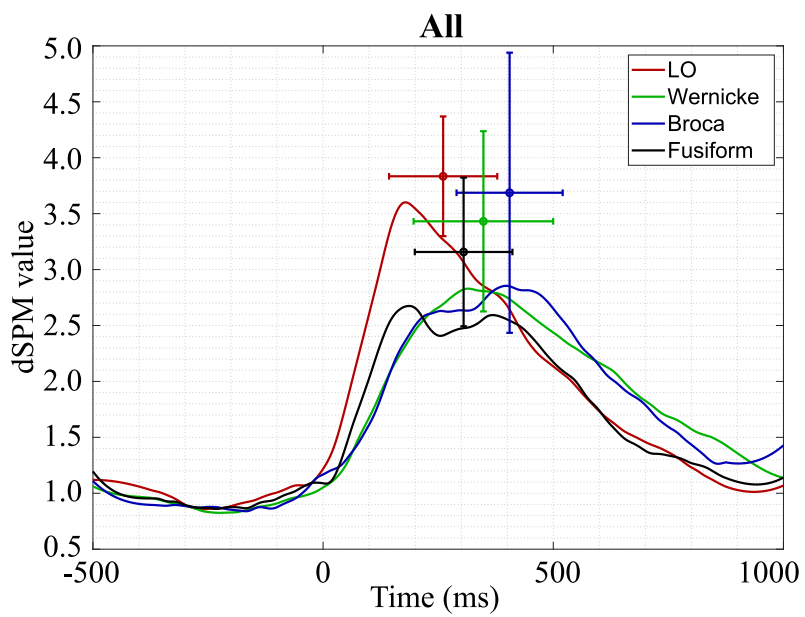

Fig. 6. Evoked response in regions of interest for all subjects (color online) $(P=31.59 \%)$. However, the intermediate FG prominent peak was still much earlier than the second BA peak $(P=93.92 \%)$.

In sum, we saw the only LO peak concurring with the first FG peak roughly near $200 \mathrm{~ms}$ (sensory processing stage), wherein the LO peak was higher than the FG peak. This was followed by two BA peaks, the second FG peak and the only WA peak. The second peaks of FG and BA, and the WA peak concurred roughly near $350 \mathrm{~ms}$ (semantic processing stage) with insignificant delays between them. Although, lacking statistical backing, the followed order of peaks was: 1) WA peak, 2) second FG peak, and 3) second BA peak. The prominent peak in BA was never the first BA peak in any group and hence, it was never selected by our peak characterising algorithm. Therefore, it is difficult to comment whether the first BA peak fell in the sensory or semantic processing stage. All notable activity in all regions of interest lasted roughly between $0-750 \mathrm{~ms}$. BA response was unusually high in Group-1 and WA response was unusually high in Group-2.

Table 6. Region-wise power analysis of mean differences of latencies and peak amplitudes over all subjects

Peak latencies

Peak amplitudes

\begin{tabular}{|c|c|c|c|c|}
\hline$\%$ & LO & WA & BA & FG \\
\hline LO & - & 73.86 & $\mathbf{9 9 . 6 9}$ & 40.66 \\
WA & - & - & 44.21 & 31.59 \\
BA & - & - & - & $\mathbf{9 3 . 9 2}$ \\
FG & - & - & - & - \\
\hline
\end{tabular}

\begin{tabular}{|c|c|c|c|c|}
\hline$\%$ & LO & WA & BA & FG \\
\hline LO & - & 67.05 & 13.52 & $\mathbf{9 8 . 9 9}$ \\
WA & - & - & 21.65 & 37.12 \\
BA & - & - & - & 58.99 \\
FG & - & - & - & - \\
\hline
\end{tabular}

2.3. Average source time-courses in subject groups. Figure 7 shows the evoked responses of each region of interest separately averaged over all subjects of a selected group.

2.3.1. Power analysis of group-wise peak latencies and amplitudes in LO. In Fig. 7, $a$ we notice that all three groups exhibit nearly unimodal LO activity. In particular, the average latencies for Group-1, 2 and 3 were 276, 187 and $334 \mathrm{~ms}$, respectively. The LO response in Group-2 was significantly earlier than in Group-1 $(P=89.67 \%)$, whereas this difference did not reach significance in case of Group-3 $(P=55.36 \%)$. However, it is easier to notice the failure of the prominent peak identification again. The identified prominent LO peaks are shifted to the right in both Group- 1 and 3 and correctly positioned only in Group-2. One may notice from simple eyeballing that the first LO peaks in both Group-1 and 3 are actually concurring with the correctly identified LO peak of Group-2. Moreover, 

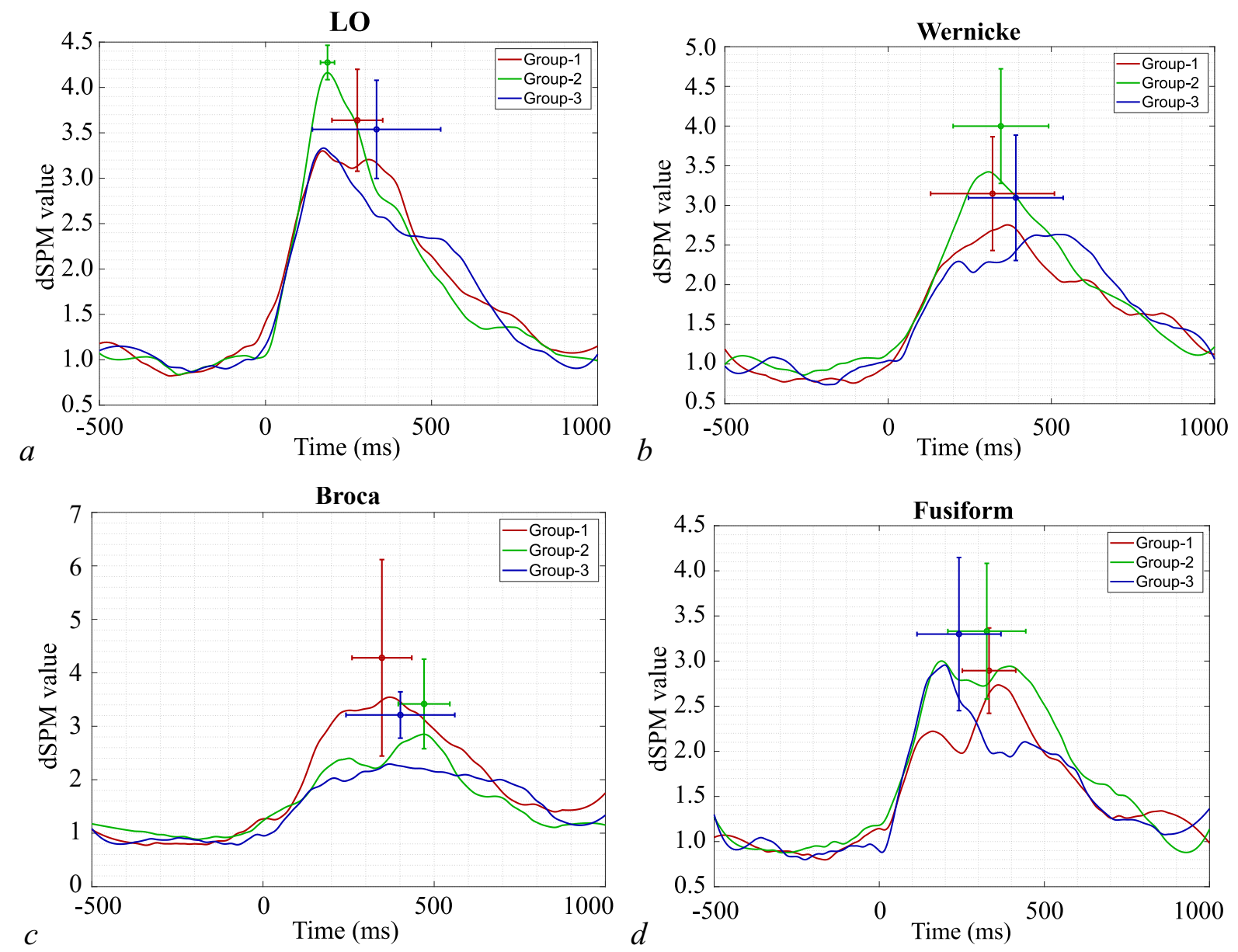

Fig. 7. Evoked response in regions of interest for all three groups of subjects (color online)

Group-2 displayed a relatively higher LO peak than Group-1 $(P=86.92 \%)$ and $3(P=89.11 \%)$. The mean amplitude of the LO response in Group-2 is very high because the response is well defined and aligned which is evident from the narrow error bars in comparison to Group-1 and 3.

2.3.2. Power analysis of group-wise peak latencies and amplitudes in WA. Further, we see higher-but-insignificant activation of WA (Fig. 7, $b)$ in Group-2 than in Group-1 ( $P=70.12 \%)$ and Group-3 $(P=57.86 \%)$. Therefore, we again see an amplified WA response in Group-2. All groups presented a unimodal waveform. All three groups had very similar mean latencies. Particularly, Group-1, 2 and 3 had mean latencies of 320, 345 and $391 \mathrm{~ms}$, respectively. The largest possible power of difference in mean latencies among the three groups was between Group- 1 and Group-3 and it was found insignificant $(P=16.17 \%)$.

2.3.3. Power analysis of group-wise peak latencies and amplitudes in BA. From Fig. 7, $c$, one can see that at least Group-1 and 2 show two prominent BA peaks. The first peak occurs at the border of the sensory and semantic processing stage, while the second peak certainly appears in the semantic processing stage, i.e., between $250-750 \mathrm{~ms}$. The prominent peak latencies were again compared for the three groups in BA and we found that the second BA peak in Group-1 was quite earlier than in Group-2 $(P=89.66 \%)$. Group-3 response lacked a clear prominent peak and had an intermediate mean latency of $388 \mathrm{~ms}$ which did not differ significantly from both Group-1 $(P=17.07 \%)$ and 2 $(P=23.35 \%)$. The Group-3 response was plateau-like and receded the last. 
2.3.4. Power analysis of group-wise peak latencies and amplitudes in FG. The evoked response in FG (Fig. 7, $d$ ) has two prominent peaks in all three groups. As noted earlier, the second peak is more prominent in Group-1, whereas the first peak is more prominent in Group-3. The highest peaks of all three groups had similar amplitudes with a maximum difference between Group-1 and Group-2 having $P=36.36 \%$. From Fig. 7, $d$, one can see that the difference lies in both the first and the second FG peaks of Group- 1 and 2 when taken together. Instead, the prominent peak analysis only allows us to compare the second FG peak of Group-1 with the first FG peak of Group-3. Both FG peaks of Group-2 had similar amplitudes that did not differ much from the highest peaks in Group-1 and 3, as noted.

Table 7. Power analysis of group-wise mean latency differences. Percentage power denoting statistical significance of differences in mean latencies of each group

LO WA

\begin{tabular}{|c|c|c|c|}
\hline$\%$ & Group-1 & Group-2 & Group-3 \\
\hline Group-1 & - & $\mathbf{8 9 . 6 7}$ & 16.22 \\
Group-2 & - & - & 55.36 \\
Group-3 & - & - & - \\
\hline
\end{tabular}

\begin{tabular}{|c|c|c|c|}
\hline$\%$ & Group-1 & Group-2 & Group-3 \\
\hline Group-1 & - & 8.69 & 16.17 \\
Group-2 & - & - & 12.62 \\
Group-3 & - & - & - \\
\hline
\end{tabular}

BA

FG

\begin{tabular}{|c|c|c|c|}
\hline$\%$ & Group-1 & Group-2 & Group-3 \\
\hline Group-1 & - & $\mathbf{8 6 . 6 0}$ & 17.07 \\
Group-2 & - & - & 23.35 \\
Group-3 & - & - & - \\
\hline
\end{tabular}

\begin{tabular}{|c|c|c|c|}
\hline$\%$ & Group-1 & Group-2 & Group-3 \\
\hline Group-1 & - & 6.45 & 39.16 \\
Group-2 & - & - & 28.66 \\
Group-3 & - & - & - \\
\hline
\end{tabular}

Table 8. Power analysis of group-wise mean peak amplitude differences. Percentage power denoting statistical significance of differences in mean peak amplitudes of each group

LO

WA

\begin{tabular}{|c|c|c|c|}
\hline$\%$ & Group-1 & Group-2 & Group-3 \\
\hline Group-1 & - & $\mathbf{8 6 . 9 2}$ & 8.78 \\
Group-2 & - & - & $\mathbf{8 9 . 1 1}$ \\
Group-3 & - & - & - \\
\hline
\end{tabular}

\begin{tabular}{|c|c|c|c|}
\hline$\%$ & Group-1 & Group-2 & Group-3 \\
\hline Group-1 & - & 70.12 & 6.28 \\
Group-2 & - & - & 57.86 \\
Group-3 & - & - & - \\
\hline
\end{tabular}

BA

FG

\begin{tabular}{|c|c|c|c|}
\hline$\%$ & Group-1 & Group-2 & Group-3 \\
\hline Group-1 & - & 30.24 & 32.05 \\
Group-2 & - & - & 12.07 \\
Group-3 & - & - & - \\
\hline
\end{tabular}

\begin{tabular}{|c|c|c|c|}
\hline$\%$ & Group-1 & Group-2 & Group-3 \\
\hline Group-1 & - & 36.36 & 24.79 \\
Group-2 & - & - & 5.71 \\
Group-3 & - & - & - \\
\hline
\end{tabular}

\section{Discussion}

ERF underlying covert naming of common objects presented in visual images were estimated for three groups of subjects with different kinds of language schooling. The observed activity demonstrated a serial response separated into different stages with distinguishable spatiotemporal activation patterns and cognitive functions [21]. The first stage of sensory processing (0-250 ms post-stimulus onset) occurred homogeneously over all groups in the same regions such as LO and FG and showed a similar temporal activation in those regions. Our results are consistent with those of the heteromodal study by Forseth et al. [19] in the 0-250 ms interval which also motivated the choice of the particular time window to study sensory processing stage in our study. 
The brain region extending anteriorly and ventrally from the lateral occipital cortex to the posterior temporal cortex responds strongly to visual stimuli containing objects that can be better identified than to fuzzy shapes [50-54]. Studies based on event-related potentials on these regions of cerebral cortex showed greater activation when observing identifiable objects compared to scrambled images [55-58]. The activated areas include parts of the LO, the ventral occipito-temporal area, the posterior and mid FG, and the occipito-temporal sulcus and are collectively referred to as the lateral occipital complex in an extensive review of functional magnetic resonance imaging (fMRI) research demonstrating the leading role of this substrate in object recognition [20].

Therefore, we expect LO and FG to be equally active for all the three groups of subjects, regardless of their language proficiency, at least at the moment corresponding to object recognition. At later stages, corresponding to the object naming, we can see inconsistency between the groups.

The subsequently investigated response was in the range $250-750 \mathrm{~ms}$ after the stimulus first appeared that corresponded to the semantic processing stage. As noted earlier, salient evoked responses in all groups and regions of interest were only seen until $750 \mathrm{~ms}$. Thus, we chose the leftover time window after sensory processing stage to represent the semantic processing stage. Widespread activity was observed in regions such as LO, BA (IFG), WA (pSTG), and FG. We found amplified response of WA in Group-2 as compared to the other groups (Fig. 7, b), although it failed to reach acceptable statistical power of $80 \%$. Whereas in Group-1, BA response instead was unusually amplified (Fig. 1). Thus, the stage of semantic processing was different for all three groups, since they differed in their language training and proficiencies. We infer that the techniques employed by the brains of these differently abled subjects were unique and depended upon their schooling. Other areas of noteworthy cognitive activity were IPS, STS, precuneus, lingual and hippocampal gyrus.

It would be helpful to compare our results with the work by Forseth et al. [19], but unfortunately, they did not define the semantic processing stage using the time axis corresponding to stimulus onset. Instead, they defined the semantic processing stage ranging from -2000 to $-1000 \mathrm{~ms}$ to articulation onset. Since our experiments used covert naming instead of overt naming, we do not have the time markers of articulation onset. In other words, a disadvantage of using the covert naming paradigm was that we did not see a clearer definition of the state of "silent"articulation that would underlie the mental speech of the selected word. Since there were virtually no words, we did not observe any activity in the sensorimotor cortex or the SMA. Nevertheless, we did observe the cortical activations migrating from the early visual cortex along the ventral and dorsal hierarchical streams [22,23] between the sensory and semantic processing stages.

We then examined the temporal response of LO, FG, BA and WA in all three groups of subjects (Fig. 5) and the global average across all subjects (Fig. 6). From the global average, we can see that at the stage of sensory processing $(0-250 \mathrm{~ms})$, activation in the visual cortex should be expected, corresponding to object recognition. The LO peak was the earliest to occur. The first FG peak during this period hypothetically corresponds to the semantic memory access required to recognise the shown object. These functions attributed to LO and FG should not be affected by their knowledge of the articulation language but only of the language in which they can implicitly name an object. Between the two BA peaks, we saw one WA peak and a second FG peak. The peak latencies for the identified second BA peaks were significantly later than for LO. Although, the difference between the LO and WA peak latencies was also nearly significantly. Especially, if we consider that the estimated LO peak is shifted to the right of the LO peak in curve (Fig. 6). Since they occur in the time interval suggested for semantic processing, we propose continuous coordinated activity between BA, WA, and FG aimed to finding the correct word of the articulation language to name the displayed object. Based on the evoked responses within the group, we observed that the LO and FG peak latencies in the early stage of sensory 
processing were the same for all three groups, while the peaks in BA, WA, and FG that belonged to the later stage of semantic processing were delayed as proficiency improved (Fig. 5). Even in the inter-group responses (Fig. 7), the peaks of the second stage were more lagging for groups with higher proficiency. Furthermore, Group-1 had the earliest BA response among the three groups (Fig. 7, c). Perhaps this is an indicator of how intermediate proficiency subjects spend their time choosing and pronouncing words in contrast to low and high proficiency subjects that either can't choose or don't require longer to choose, respectively.

Interestingly, the second FG peak was lower than first FG peak in Group 3, as opposed to Groups 1 and 2. If we suppose that FG does represent lexical access once in the subject's native language during the sensory processing stage, then in the articulation language at the stage of semantic processing, the appearance of lower second peak for Group 3 is reasonable, since the proficiency in the articulation language is native-like. However, for Groups 1 and 2, the two peaks corresponding to naming the object in the native and articulation languages, respectively, are either equally high or the second peak is higher than the first, demonstrating more effort to name an object in a foreign language. Moreover, the occurrence of semantic memory access during sensory processing also supports the idea that the memories of the past guide the perception of the present.

Finally, activations of language-related areas such as BA (Fig. 7, $c$ ) and WA (Fig. 7, b) in Group-1 and 2 were higher than in Group-3. Phonological processing and word formation in a foreign language will require additional effort, and this may be the reason why we see the highest BA response in Group 1 with the lowest proficiency and why it decreases as the proficiency increases. Group-2 may have a better understanding of the phonological aspects, but struggles with word selection. Therefore, we see the WA response in Group-2 is higher than in Group-1 and 3.

3.1. Limitations of the study and future directions. This study was admittedly limited in its sample size and further work is needed to statistically back up the likely trends and mechanisms proposed in this paper. The role of IPS was not explored in the same manner as the other studied areas and can turn out to be the missing piece in describing how the FG, BA, and WA are communicating during the semantic processing stage. Lastly, the method for identifying prominent peaks needs to be developed in the future. The method works well for homogeneous unimodal responses or in cases of multimodal responses where the peak of interest is always at a particular prominence ranking with the other peaks. The method easily fails in cases where multiple peaks of similar prominence concur and the resulting peak is located at the centre of those peaks. A possible direction could be to look at projecting the individual evoked responses to a common average evoked response and extracting the evoked response features from that projection.

The study was planned to have roughly the same number of male and female participants. However, due to odd numbers of total participants and participants per group, it was not possible to have an exactly balanced gender ratio. Moreover, due to the later exclusion of subject 7, the ratio was further skewed. The used methods and analysis pipelines are publicly available at https://github.com/pchholak/picname and can be readily used in other studies to ensure conformity of analysis methods.

\section{Conclusions}

We have conducted a series of MEG experiments based on the covert picture-naming task with fourteen non-native English speakers, who made up three groups with different kinds of language training and proficiencies. We found two stages of brain response, corresponding to sensory and semantic processing, which differed in spatio-temporal cortical activation. The active regions found in our twostage response are consistent with the active regions found in other studies based on techniques such as 
fMRI, ECoG, and direct electrical stimulation. The sensory processing stage remained uniform across the three differently proficient groups, whereas the semantic processing stage showed inconsistencies. A new understanding of the mechanisms of covertly naming pictures and their neuronal substrate has been obtained. The complete mechanism of the semantic processing stage seems to be much more complex and requires further work. It seems that there are bidirectional connections between the three-focal network formed by fusiform gyrus, Broca's area, and Wernicke's area, and their causal relationships need to be investigated in the future. The connections of this network with the intraparietal sulcus also need to be investigated. In addition, a robust method to identify evoked response peaks needs to be developed in future. Finally, this work highlights the importance of fusiform gyrus, which is at risk of resection in mesial temporal lobe epilepsies.

\section{References}

1. Quillian M. Semantic memory. In: Minsky M, editor. Semantic Information Processing. Cambridge, MA: MIT Press; 1968. P. 216-270.

2. Tulving E. Episodic and semantic memory. In: Tulving E, Donaldson W, editors. Organization of Memory. New York: Academic Press; 1972. P. 381-403.

3. Warrington EK. The selective impairment of semantic memory. Q. J. Exp. Psychol. 1975;27(4):635657. DOI: $10.1080 / 14640747508400525$.

4. Nestor PJ, Fryer TD, Hodges JR. Declarative memory impairments in Alzheimer's disease and semantic dementia. NeuroImage. 2006;30(3):1010-1020. DOI: 10.1016/j.neuroimage.2005.10.008.

5. Burnstine TH, Lesser RP, Hart J, Uematsu S, Zinreich SJ, Krauss GL, Fisher RS, Vining EPG, Gordon B. Characterization of the basal temporal language area in patients with left temporal lobe epilepsy. Neurology. 1990;40(6):966-970. DOI: 10.1212/WNL.40.6.966.

6. Lüders H, Lesser RP, Hahn J, Dinner DS, Morris HH, Wyllie E, Godoy J. Basal temporal language area. Brain. 1991;114(2):743-754. DOI: 10.1093/brain/114.2.743.

7. Damasio H, Grabowski TJ, Tranel D, Hichwa RD, Damasio AR. A neural basis for lexical retrieval. Nature. 1996;380(6574):499-505. DOI: 10.1038/380499a0.

8. Noppeney U, Price CJ. A PET study of stimulus- and task-induced semantic processing. NeuroImage. 2002;15(4):927-935. DOI: 10.1006/nimg.2001.1015.

9. Bright P, Moss H, Tyler LK. Unitary vs multiple semantics: PET studies of word and picture processing. Brain Lang. 2004;89(3):417-432. DOI: 10.1016/j.bandl.2004.01.010.

10. Sharp DJ, Scott SK, Wise RJS. Retrieving meaning after temporal lobe infarction: The role of the basal language area. Ann. Neurol. 2004;56(6):836-846. DOI: 10.1002/ana.20294.

11. Spitsyna G, Warren JE, Scott SK, Turkheimer FE, Wise RJS. Converging language streams in the human temporal lobe. J. Neurosci. 2006;26(28):7328-7336.

DOI: 10.1523/JNEUROSCI.0559-06.2006.

12. Marinkovic K, Dhond RP, Dale AM, Glessner M, Carr V, Halgren E. Spatiotemporal dynamics of modality-specific and supramodal word processing. Neuron. 2003;38(3):487-497.

DOI: 10.1016/S0896-6273(03)00197-1.

13. Nobre AC, Allison T, McCarthy G. Word recognition in the human inferior temporal lobe. Nature. 1994;372(6503):260-263. DOI: 10.1038/372260a0.

14. Liu H, Agam Y, Madsen JR, Kreiman G. Timing, timing, timing: Fast decoding of object information from intracranial field potentials in human visual cortex. Neuron. 2009;62(2): 281-290. DOI: 10.1016/j.neuron.2009.02.025.

15. Mesulam MM. From sensation to cognition. Brain. 1998;121(6):1013-1052.

DOI: $10.1093 /$ brain/121.6.1013.

16. Thompson-Schill SL. Neuroimaging studies of semantic memory: inferring «how» from «where». Neuropsychologia. 2003;41(3):280-292. DOI: 10.1016/S0028-3932(02)00161-6. 
17. Catani M, Ffytche DH. The rises and falls of disconnection syndromes. Brain. 2005;128(10): 2224-2239. DOI: 10.1093/brain/awh622.

18. Martin A. The representation of object concepts in the brain. Annu. Rev. Psychol. 2007;58:25-45. DOI: 10.1146/annurev.psych.57.102904.190143.

19. Forseth KJ, Kadipasaoglu CM, Conner CR, Hickok G, Knight RT, Tandon N. A lexical semantic hub for heteromodal naming in middle fusiform gyrus. Brain. 2018;141(7):2112-2126. DOI: $10.1093 /$ brain/awy120.

20. Grill-Spector K, Kourtzi Z, Kanwisher N. The lateral occipital complex and its role in object recognition. Vis. Res. 2001;41(10-11):1409-1422. DOI: 10.1016/S0042-6989(01)00073-6.

21. Indefrey P, Levelt WJM. The spatial and temporal signatures of word production components. Cognition. 2004;92(1-2):101-144. DOI: 10.1016/j.cognition.2002.06.001.

22. Ungerleider LG, Mishkin M. Two cortical visual systems. In: Ingle DJ, Goodale MA, Mansfield RJW, editors. Analysis of Visual Behavior. Cambridge: MIT Press; 1982. P. 549-586.

23. Felleman DJ, Van Essen DC. Distributed hierarchical processing in the primate cerebral cortex. Cereb. Cortex. 1991;1(1):1-47. DOI: 10.1093/cercor/1.1.1-a.

24. Thompson-Shill SL, D'Esposito M, Aguirre GK, Farah MJ. Role of left inferior prefrontal cortex in retrieval of semantic knowledge: A reevaluation. Proc. Natl. Acad. Sci. U.S.A. 1997;94(26): 14792-14797. DOI: 10.1073/pnas.94.26.14792.

25. Wagner AD, Paré-Blagoev EJ, Clark J, Poldrack RA. Recovering meaning: Left prefrontal cortex guides controlled semantic retrieval. Neuron. 2001;31(2):329-338.

DOI: 10.1016/S0896-6273(01)00359-2.

26. Hickok G, Poeppel D. The cortical organization of speech processing. Nat. Rev. Neurosci. 2007;8(5):393-402. DOI: 10.1038/nrn2113.

27. Poldrack RA, Wagner AD, Prull MW, Desmond JE, Glover GH, Gabrieli JDE. Functional specialization for semantic and phonological processing in the left inferior prefrontal cortex. NeuroImage. 1999;10(1):15-35. DOI: 10.1006/nimg.1999.0441.

28. Badre D, Poldrack RA, Paré-Blagoev EJ, Insler RZ, Wagner AD. Dissociable controlled retrieval and generalized selection mechanisms in ventrolateral prefrontal cortex. Neuron. 2005;47(6):907918. DOI: 10.1016/j.neuron.2005.07.023.

29. Bastos AM, Vezoli J, Bosman CA, Schoffelen JM, Oostenveld R, Dowdall JR, De Weerd P, Kennedy H, Fries P. Visual areas exert feedforward and feedback influences through distinct frequency channels. Neuron. 2015;85(2):390-401. DOI: 10.1016/j.neuron.2014.12.018.

30. Michalareas G, Vezoli J, van Pelt S, Schoffelen JM, Kennedy H, Fries P. Alpha-beta and gamma rhythms subserve feedback and feedforward influences among human visual cortical areas. Neuron. 2016;89(2):384-397. DOI: 10.1016/j.neuron.2015.12.018.

31. Lazar RM, Mohr JP. Revisiting the contributions of Paul Broca to the study of aphasia. Neuropsychol. Rev. 2011;21(3):236-239. DOI: 10.1007/s11065-011-9176-8.

32. Trupe LA, Varma DD, Gomez Y, Race D, Leigh R, Hillis AE, Gottesman RF. Chronic apraxia of speech and Broca's area. Stroke. 2013;44(3):740-744. DOI: 10.1161/STROKEAHA.112.678508.

33. Flinker A, Korzeniewska A, Shestyuk AY, Franaszczuk PJ, Dronkers NF, Knight RT, Crone NE. Redefining the role of Broca's area in speech. Proc. Natl. Acad. Sci. U.S.A. 2015;112(9): 2871-2875. DOI: 10.1073/pnas.1414491112.

34. Chao LL, Martin A. Representation of manipulable man-made objects in the dorsal stream. NeuroImage. 2000;12(4):478-484. DOI: 10.1006/nimg.2000.0635.

35. Binder JR, Desai RH. The neurobiology of semantic memory. Trends Cogn. Sci. 2011;15(11): 527-536. DOI: 10.1016/j.tics.2011.10.001.

36. Conner CR, Chen G, Pieters TA, Tandon N. Category specific spatial dissociations of parallel processes underlying visual naming. Cereb. Cortex. 2014;24(10):2741-2750.

DOI: $10.1093 /$ cercor/bht130. 
37. Binney RJ, Embleton KV, Jefferies E, Parker GJ, Lambon Ralph MA. The ventral and inferolateral aspects of the anterior temporal lobe are crucial in semantic memory: Evidence from a novel direct comparison of distortion-corrected fMRI, rTMS, and semantic dementia. Cereb. Cortex. 2010;20(11):2728-2738. DOI: 10.1093/cercor/bhq019.

38. Mion M, Patterson K, Acosta-Cabronero J, Pengas G, Izquierdo-Garcia D, Hong YT, Fryer TD, Williams GB, Hodges JR, Nestor PJ. What the left and right anterior fusiform gyri tell us about semantic memory. Brain. 2010;133(11):3256-3268. DOI: 10.1093/brain/awq272.

39. Noppeney U, Phillips J, Price C. The neural areas that control the retrieval and selection of semantics. Neuropsychologia. 2004;42(9):1269-1280.

DOI: 10.1016/j.neuropsychologia.2003.12.014.

40. Binder JR. The Wernicke area: Modern evidence and a reinterpretation. Neurology. 2015;85(24): 2170-2175. DOI: 10.1212/WNL.0000000000002219.

41. Drane DL, Loring DW, Voets NL, Price M, Ojemann JG, Willie JT, Saindane AM, Phatak V, Ivanisevic M, Millis S, Helmers SL, Miller JM, Meador KJ, Gross RE. Better object recognition and naming outcome with MRI-guided stereotactic laser amygdalohippocampotomy for temporal lobe epilepsy. Epilepsia. 2015;56(1):101-113. DOI: 10.1111/epi.12860.

42. Hoppe C, Witt JA, Helmstaedter C, Gasser T, Vatter H, Elger CE. Laser interstitial thermotherapy (LiTT) in epilepsy surgery. Seizure. 2017;48:45-52. DOI: 10.1016/j.seizure.2017.04.002.

43. Oldfield RC. The assessment and analysis of handedness: The Edinburgh inventory. Neuropsychologia. 1971;9(1):97-113. DOI: 10.1016/0028-3932(71)90067-4.

44. Genesee F. Second language learning through immersion: A review of U.S. programs. Rev. Educ. Res. 1985;55(4):541-561. DOI: 10.2307/1170246.

45. Gramfort A, Luessi M, Larson E, Engemann DA, Strohmeier D, Brodbeck C, Parkkonen L, Hämäläinen MS. MNE software for processing MEG and EEG data. NeuroImage. 2014;86: 446-460. DOI: 10.1016/j.neuroimage.2013.10.027.

46. Peirce JW. PsychoPy-Psychophysics software in Python. J. Neurosci. Methods. 2007;162(1-2): 8-13. DOI: 10.1016/j.jneumeth.2006.11.017.

47. Niso G, Gorgolewski KJ, Bock E, Brooks TL, Flandin G, Gramfort A, Henson RN, Jas M, Litvak V, Moreau JT, Oostenveld R, Schoffelen JM, Tadel F, Wexler J, Baillet S. MEG-BIDS, the brain imaging data structure extended to magnetoencephalography. Sci. Data. 2018;5(1):180110. DOI: $10.1038 /$ sdata.2018.110.

48. Fischl B. FreeSurfer. NeuroImage. 2012;62(2):774-781. DOI: 10.1016/j.neuroimage.2012.01.021.

49. Dale AM, Liu AK, Fischl BR, Buckner RL, Belliveau JW, Lewine JD, Halgren E. Dynamic statistical parametric mapping: Combining fMRI and MEG for high-resolution imaging of cortical activity. Neuron. 2000;26(1):55-67. DOI: 10.1016/S0896-6273(00)81138-1.

50. Grill-Spector K, Kushnir T, Hendler T, Edelman S, Itzchak Y, Malach R. A sequence of objectprocessing stages revealed by fMRI in the human occipital lobe. Hum. Brain Mapp. 1998;6(4): 316-328. DOI: 10.1002/(SICI)1097-0193(1998)6:4<316::AID-HBM9>3.0.CO;2-6.

51. Grill-Spector K, Kushnir T, Edelman S, Itzchak Y, Malach R. Cue-invariant activation in objectrelated areas of the human occipital lobe. Neuron. 1998;21(1):191-202.

DOI: 10.1016/S0896-6273(00)80526-7.

52. Murtha S, Chertkow H, Beauregard M, Evans A. The neural substrate of picture naming. J. Cogn. Neurosci. 1999;11(4):399-423. DOI: 10.1162/089892999563508.

53. Kourtzi Z, Kanwisher N. Cortical regions involved in perceiving object shape. J. Neurosci. 2000;20(9):3310-3318. DOI: 10.1523/JNEUROSCI.20-09-03310.2000.

54. Doniger GM, Foxe JJ, Murray MM, Higgins BA, Snodgrass JG, Schroeder CE, Javitt DC. Activation timecourse of ventral visual stream object-recognition areas: High density electrical mapping of perceptual closure processes. J. Cogn. Neurosci. 2000;12(4):615-621.

DOI: $10.1162 / 089892900562372$. 
55. Allison T, Ginter H, McCarthy G, Nobre AC, Puce A, Luby M, Spencer DD. Face recognition in human extrastriate cortex. J. Neurophysiol. 1994;71(2):821-825. DOI: 10.1152/jn.1994.71.2.821.

56. Allison T, Puce A, Spencer DD, McCarthy G. Electrophysiological studies of human face perception. I: Potentials generated in occipitotemporal cortex by face and non-face stimuli. Cereb. Cortex. 1999;9(5):415-430. DOI: 10.1093/cercor/9.5.415.

57. McCarthy G, Puce A, Belger A, Allison T. Electrophysiological studies of human face perception. II: Response properties of face-specific potentials generated in occipitotemporal cortex. Cereb. Cortex. 1999;9(5):431-444. DOI: 10.1093/cercor/9.5.431.

58. Puce A, Allison T, McCarthy G. Electrophysiological studies of human face perception. III: Effects of top-down processing on face-specific potentials. Cereb. Cortex. 1999;9(5):445-458. DOI: $10.1093 /$ cercor/9.5.445.

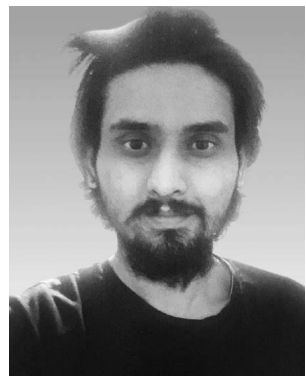

Парт Чхолак - родился в Джайпуре, Индия (1995). Окончил Индийский технологический институт Бомбея (2017) по специальности инженер-механик. Получил степень магистра (2018) биомедицинской инженерии в Мадридском политехническом университете, Испания. Научные интересы: нейробиология, нелинейная теория. Является автором 20 публикаций, поддержанных грантами промышленности и Российского научного фонда. Активный член Международного общества физики и управления в России и Сети ALBA в Бельгии.

Испания, Мадрид

Мадридский политехнический университет

E-mail: parth.chholak@ctb.upm.es

ORCID: 0000-0002-6437-7750

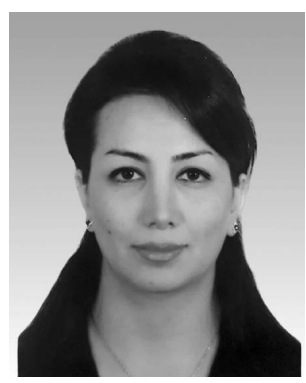

Фатеме Табари - родилась в Ширазе, Иран (1984). Окончила Университет Ясудж по специальности «английский язык и литература» (2007). Защитила диссертацию на тему «Нейронная сигнатура двуязычия» (2020, Мадридский автономный университет). Научные интересы: нейронные основы и связи, которые контролируют понимание, выработку и усвоение языка у здорового и патологического населения с помощью применения электрофизиологических методов. Автор нескольких научных статей и главы в книге. Является научным рецензентом журнала «Литература и языкознание». Получила грант Женевского университета (2017-2018) и работала в качестве приглашенного исследователя в Лаборатории мозга и языка, кампус биотехнологии. Активный член испанского общества Española de Psicofisiología y Neurociencia Cognitiva y Afectiva (SEPNECA).

Испания, Мадрид

Мадридский автономный университет

E-mail: fatemeh.tabari@estudiante.uam.es

ORCID: 0000-0002-4572-3283

Писарчик Александр Николаевич - кандидат физико-математических наук, профессор. Ведущий научный сотрудник Центра биомедицинских технологий Политехнического университета Мадрида и Университета Иннополис. Научные интересы - теория хаоса, синхронизация, мультистабильность, стохастические процессы и прерывистость, с приложениями к электронным, оптическим и биомедицинским системам. Автор 5 монографий, 17 глав книг, 10 патентов и более 280 статей в рецензируемых научных журналах. Под его руководством успешно защищено 10 диссертаций (Ph.D.) и завершено 30 научно-исследовательских проектов, в том числе Российского научного фонда. Является членом правления Международного общества физики и контроля (IPACS), Консорциума биомедицинских исследований в сети (CYBER) (Испания), а также Европейского, Итальянского и Мексиканского физических обществ.

Испания, Мадрид

Мадридский политехнический университет

Россия, 420500 Иннополис, ул. Университетская, 1

Университет Иннополис

E-mail: alexander.pisarchik@ctb.upm.es

ORCID: 0000-0003-2471-2507 